\title{
Dating the Kawakawa/Oruanui eruption: Comment on "Optical luminescence dating of a loess section containing a critical tephra marker horizon, SW North Island of New Zealand" by R. Grapes et al.
}

\author{
David J. Lowe $^{\text {a,*, C.J.N. Wilson }}{ }^{\text {, }}$, R.M. Newnham ${ }^{c}$ and A.G. Hogg \\ ${ }^{a}$ Department of Earth and Ocean Sciences, University of Waikato, Private Bag 3105, \\ Hamilton 3240, New Zealand \\ ${ }^{\mathrm{b}}$ School of Geography, Environment and Earth Sciences, Victoria University of Wellington, \\ P.O. Box 600, Wellington 6140, New Zealand \\ ${ }^{c}$ School of Geography, Earth and Environmental Sciences, University of Plymouth, Plymouth \\ PLA 8AA, U.K. \\ ${ }^{\mathrm{d}}$ Waikato Radiocarbon Dating Laboratory, University of Waikato, Private Bag 3105, \\ Hamilton 3240, New Zealand
}

Final pre-publication manuscript as follows:

Lowe, D.J., Wilson, C.J.N., Newnham, R.M., Hogg, A.G. 2010. Dating the Kawakawa/Oruanui eruption: comment on "Optical luminescence dating of a loess section containing a critical tephra marker horizon, SW North Island of New Zealand" by R. Grapes et al. Quaternary Geochronogy 5, 493-496.

*Corresponding author. Tel.: +64 78384438

Email addresses: d.lowe@waikato.ac.nz (D.J. Lowe), colin.wilson@vuw.ac.nz (C.J.N. Wilson), r.newnham@plymouth.ac.uk (R.M. Newnham), alan.hogg@waikato.ac.nz (A.G. Hogg). 


\begin{abstract}
An IRSL age of $17.0 \pm 2.2 \mathrm{ka}$ (and a "mean age" of ca. $19 \mathrm{ka}$ ) reported by Grapes et al. [Grapes, R., Rieser, U., Wang, N. Optical luminescence dating of a loess section containing a critical tephra marker horizon, SW North Island of New Zealand. Quaternary Geochronology 5(2-3), 164-169.] for the Kawakawa/Oruanui tephra, and other ages associated with a loess section in New Zealand, are untenable: age data presented are inconsistent, no formal statistical treatments or error determinations were undertaken in age analysis, and the ages proposed are seriously at odds with multiple radiocarbon age determinations on tephra sequences bracketing the Kawakawa/Oruanui tephra and with palaeoenvironmental evidence elsewhere for the time period concerned. We suggest that the bulk polymineral IRSL ages on the tephra and encapsulating loess deposits were underestimated in part because of contamination of the loess by the integration of younger materials during slow deposition and continuous modification by upbuilding pedogenesis. Single-grain luminescence assays may reveal such contamination. A ${ }^{14} \mathrm{C}$-based age of ca. $27 \pm 1 \mathrm{ka}$ cal BP $(2 \sigma)$, reported in 2008 , currently remains the best estimate for the age of eruption of the Kawakawa/Oruanui tephra.
\end{abstract}

\title{
Keywords:
}

Luminescence dating; ${ }^{14} \mathrm{C}$ dating; isochron; Kawakawa tephra; Oruanui eruption; LGM; loess; New Zealand 


\section{Introduction}

The complexities of radiometric dating require that all factors including site selection, sample type and pre-treatment, laboratory procedures, and age data analysis, are optimal to obtain accurate and precise ages. We therefore respect the efforts of Grapes et al. (2010) to re-date the Kawakawa tephra (also known as Oruanui tephra and hereafter referred to as Kawakawa/Oruanui tephra or KOT) in a sequence of loess in New Zealand using infraredstimulated luminescence (IRSL). Unfortunately, the IRSL age of ca. $17.0 \pm 2.2 \mathrm{ka}$ obtained on the KOT by Grapes et al. (2010) is, in our view, flawed and hence misleading for several reasons, given below. Instead, we favour a significantly older age of ca. 26-28 ka (95\% probability) for the KOT derived from the calibration of four optimum radiocarbon $\left({ }^{14} \mathrm{C}\right)$ ages which are consistent with, and supported by, independent tephrostratigraphic and palaeoenvironmental data (e.g., Lowe et al., 2008a). We do not agree that there is an "unresolved discrepancy between the two dating systems" as concluded by Grapes et al. (2010) - available data suggest that the luminescence age is much more likely to be erroneous than the ${ }^{14} \mathrm{C}$ age. In our criticisms we firstly comment on the presentation and analysis of the luminescence ages. We record inconsistencies in the age data and note that no formal statistical analyses were undertaken and no errors determined in deriving a putative "mean age" of ca. $19 \mathrm{ka}$ for the KOT. Secondly, we suggest some possible reasons (additional to those of Grapes et al., 2010) as to why the IRSL ages for the KOT, and possibly loess samples more generally, could be underestimated. Thirdly, we outline tephrostratigraphic and palaeoenvironmental considerations relating to the age of the KOT and show that an age of ca. $27 \mathrm{ka}$ is viable whereas one of ca. $17 \mathrm{ka}$ is not. 
As noted by Grapes et al. (2010), the KOT is the most voluminous and widespread late Quaternary tephra marker bed in the New Zealand region (Wilson, 2001; Lowe et al., 2008a). Its importance as an isochron in linking, synchronizing, and dating a range of terrestrial and marine palaeoevironmental records and palaeoclimatic events has been repeatedly emphasised (e.g., Pillans et al., 1993; Alloway et al., 2007; Newnham et al., 2007a; Carter et al., 2008). Its age is therefore of considerable significance and interest.

\section{Presentation and analysis of the luminescence ages}

Grapes et al. (2010) reported eight new IRSL ages relating to a loess-dominated section containing the KOT on an elevated alluvial terrace adjacent to the Rangitikei River in southern North Island. The ages (reported in Table S2 of Grapes et al., 2010) were calculated from IRSL signals obtained from polymineral 4-11- $\mu \mathrm{m}$ fractions obtained from bulk samples of loess together with one bulk sample of the KOT. Grapes et al. (2010) stated that the IRSL signals in the loess samples were derived from feldspar grains and additionally possibly from glass shards in the tephra sample. The age obtained for the KOT (field number PLT, lab number WLL736) was reported as $16.6 \pm 2.2 \mathrm{ka}$ in Table S2 but as $16.2 \pm 2.2 \mathrm{ka}$ in the text; loess immediately above the KOT (PLL-3/WLL731) was reported as $16.5 \pm 1.4 \mathrm{ka}$ in Table $\mathrm{S} 2$ but as $17.6 \pm 1.2 \mathrm{ka}$ in the text; and loess immediately below the KOT (PLL-4/WLL732) was reported as $17.6 \pm 1.2 \mathrm{ka}$ in Table $\mathrm{S} 2$ but as $18.0 \pm 1.3 \mathrm{ka}$ in the text. To compound these inconsistencies, the new IRSL age for the KOT in the abstract was reported to be $17.0 \pm 2.2$ $\mathrm{ka}$. Thus it is unclear as to which of the three IRSL ages $(16.6 \pm 2.2,16.2 \pm 2.2,17.0 \pm 2.2$ ka) is the correct one for the KOT (and ages of the encapsulating loess samples are also ambiguous).

The measurement errors around the ages reported in Table S2 mostly range from ca. 1000 to 2000 years but the levels of significance of the error terms were not reported. By 
implicit convention, luminescence ages are normally reported at 1 standard deviation (M.D. Bateman pers. comm., 2009). Assuming that the age errors in Table S2 represent 1 standard deviation then the 2 standard deviation range for sample PLT/WLL736 on the KOT is likely to be as much as ca. 4400 years. Such imprecision means that discussions about discrepancies between luminescence and ${ }^{14} \mathrm{C}$ ages are compromised to some extent.

Furthermore, it was suggested that these new ages, when considered alongside previously obtained luminescence ages (both published and unpublished) from deposits adjacent to the KOT, and on KOT itself, "imply a mean age of ca. 19 ka for the tephra". Exactly how this "mean age" was derived, and from which ages, is not stated and yielded an unacceptably arbitrary figure. Grapes et al. (2010) referred to Fig. 3, which is a plot of the sampling positions of 21 luminescence ages on a composite stratigraphic column. Of these, only about seven samples are plotted within approximately $5 \mathrm{~cm}$ distance above or below the KOT and so possibly are relevant to its age. The rest are some decimetres away from the tephra stratigraphically and hence potentially many hundreds or thousands of years (depending on sedimentation rates) older or younger. Error terms were not considered in deriving the "mean age" of ca. $19 \mathrm{ka}$ and so its value is even more questionable given the significant errors on the raw IRSL ages in Table S2. Possibly Bayesian-based age modelling techniques, which include formal outlier identification, could have helped Grapes et al. (2010) utilize their full sequence of dates more effectively (e.g., Buck et al., 2003; Blaauw et al., 2007; Blockley et al., 2007; Bronk Ramsey, 2008). Such techniques have been employed for tephra-containing peat sequences whereby all ages in stratigraphic order are used together to obtain ages for each part of the sequence with known probability (Hajdas et al., 2006; Lowe et al., 2008a). 


\section{Possible sources of error}

Grapes et al. (2010) considered some possible sources of error that might explain why their IRSL dates may be too young. One source considered was that of $U$ and Th sequestration in $\mathrm{CaCO}_{3}$, as invoked by Almond et al. (2007) who studied carbonate-rich loess at Banks Peninsula, South Island. However, $\mathrm{CaCO}_{3}$ is not present in loess sequences in southern North Island and hence is irrelevant here. A second source of error considered was that of anomalous fading of feldspars, but that was discounted because it had not been evident in fading tests undertaken, and because the results were said to be comparable to those derived from quartz analysed at nearby locations by Shepherd and Price (1990), who suggested a thermoluminescence age for the KOT of 24,200 $\pm 3700 \mathrm{ka}(1 \sigma)$ (see also Duller, 1994, 1996). Thirdly, Grapes et al. (2010) discussed post-depositional translocation of U, Th, and $\mathrm{K}$ downward through the loess column but concluded that any such contamination had been minor. This conclusion was based on data plotted in Fig. 5 and on the observation that rootlet-contaminated samples of the KOT in South Island loess dated by Berger et al. (1994) were "virtually identical" to other luminescence ages on the KOT. Our contention here would be that two wrongs do not necessarily make a right and that perhaps another mechanism for the enrichment of $\mathrm{U}, \mathrm{Th}$, and $\mathrm{K}$ in loess samples, and thus underestimation of ages, has been overlooked. We speculate that the process of continuous soil formation in accumulating loess, known as upbuilding pedogenesis, may be responsible here in part for the contamination of loess by younger $\mathrm{U}$ and $\mathrm{Th}$, both in southern North Island and potentially elsewhere where loess was accumulating at similarly slow rates. During periods when loess is accumulating, soil formation (pedogenesis) does not stop, but its effects are lessened because any one position in the loess deposit is not exposed to soil processes for long before it is buried too deeply for these processes to be effective (Lowe et al., 2008b). Nevertheless, this upbuilding history leaves the loess deposit with a soil fabric inherited from when the loess was part of 
the land surface and represented by soil A horizons (also B horizons). Soil formation thus occurs simultaneously with slow loess accumulation, forming a 'soil-sediment'. In New Zealand, the average rates of net loess accumulation since deposition of the KOT and before the Holocene are only ca. 3 to $10 \mathrm{~mm}$ per century (Eden and Hammond, 2003; Lowe et al., 2008b). The implication is that modern $\mathrm{U}$ and Th are continuously incorporated into the loess as the land surface slowly rises, and hence measured values reflect the integration of amounts already present and that being acquired. Thus luminescence ages, inevitably, are likely to be too young. We also note that Grapes et al. (2010) showed little variation in potassium content (as wt \%) with depth in Fig. 5, a result that contrasts with the findings of Palmer and Pillans (1996) who showed wide variations in $\mathrm{K}_{2} \mathrm{O}$ (wt \%) values in loess at a section near Wanganui in southern North Island. An explanation for this difference may be in sampling resolution with Grapes et al. (2010) analysing only eight samples in a sequence spanning ca. $5.5 \mathrm{~m}$ whereas Palmer and Pillans (1996) sampled in 100-mm increments over a 16 m-long sequence.

Various potential error sources in dating volcanic and related sediments using luminescence were reviewed by Fattahi and Stokes (2003). Other possible sources include post-depositional bioturbation, as described by Bateman et al. (2007), which produces inaccurate luminescence ages. Another, perhaps most importantly, is that luminescence analyses of bulk or multi-grain samples can be compromised because some individual grains may yield anomalous results (Duller, 2004; Demuro et al., 2008). Therefore single-grain analyses, where feasible, have been deemed necessary to overcome any potential 'ageshortfall' or other anomaly that may arise from multi-grain analyses. Moreover, Demuro et al. (2008) showed through single-grain analysis of quartz (on grains from the 180-212 $\mu$ m-size fraction) that accordant ${ }^{14} \mathrm{C}$ and luminescent ages were obtainable for the Dawson tephra in Yukon Territory, Canada, which was erupted ca. $30.2 \pm 0.2 \mathrm{ka}$ cal BP $(2 \sigma)$. 


\section{Stratigraphic and palaeoenvironmental considerations}

A fundamental principle in geochronology is that any age estimates, how ever derived, should be assessed against independent stratigraphic criteria where these exist. Fortunately in this case, much is known about the chronostratigraphic and depositional context in which the KOT was deposited.

The IRSL age of ca. $17 \mathrm{ka}$ for the KOT is inconsistent with tephrostratigraphic evidence summarised by Lowe et al. (2008a) that further indicates that the IRSL ages must be too young. Three tephras, Te Rere, Okareka, and Rerewhakaaitu, with intervening paleosols, all overlie the KOT stratigraphically and hence must be younger, yet give calibrated ages that are older than ca. $17 \mathrm{ka}$ : Te Rere tephra is $25.3 \pm 0.8 \mathrm{ka}$ cal BP $(2 \sigma)$, Okareka tephra is $21.8 \pm$ $0.5 \mathrm{ka}$ cal BP $(2 \sigma)$, and Rerewhakaaitu tephra is $17.6 \pm 0.4 \mathrm{ka}$ cal BP $(2 \sigma)$. The last age on Rerewhakaaitu tephra is likely to be very reliable because it was derived by Bayesian-based wiggle-match analyses of 51 dates from a long tephra-bearing peat sequence using OxCal (Hajdas et al., 2006). The age was supported by independent analysis using Bpeat that yielded an age of $17.7 \pm 0.3 \mathrm{ka}$ cal $\mathrm{BP}(2 \sigma)$ (Lowe et al., 2008a).

A wide range of stratigraphic data indicates that the KOT was deposited early in the so-called 'extended' Last Glacial Maximum (eLGM) in the New Zealand region (Manville and Wilson, 2004; Suggate and Almond, 2005; Vandergoes et al., 2005; Litchfield and Berryman, 2005; Alloway et al., 2007; Newnham et al., 2007a, b). Loess deposition throughout the southern North Island was probably at a maximum through the eLGM but ceased around or soon after the time of deposition of the Rerewhakaaitu tephra; this tephra isochron also marks the start of extensive re-afforestation in northern North Island (Newnham et al., 2003). Abandonment of fluvial terraces and the onset of incision probably began approximately simultaneously at around this time in all catchments in eastern North Island in response to decreased sediment supply, increased stream power, and increased rainfall 
(Litchfield and Berryman, 2006; Alloway et al., 2007). The onset of warming, inferred from speleothem and marine records, occurred ca. 18.0 ka (Alloway et al., 2007; Lowe et al., 2008a). Thus the IRSL age of ca. $17.0 \mathrm{ka}$ for the KOT in the Rangitikei valley is demonstrably incompatible with independent palaeoenvironmental and stratigraphic evidence at numerous sites for the timing of loess deposition and its cessation.

Although minor loess (or aeolian dust) continued to be deposited in the Holocene in the North Island, rates of deposition were extremely slow and measurable quantities occur only close to sources (Lowe et al., 2008b; Marx et al., 2009). The inference by Grapes et al. (2010) that sample PLL-7/WLL735, barely $0.6 \mathrm{~m}$ below the terrace surface at Rangitikei and with an IRSL age of ca. $4.8 \pm 0.5 \mathrm{ka}$, represents substantial ongoing loess deposition in the mid-Holocene is highly questionable in view of the extensive palaeoenvironmental evidence which suggests that almost all loess deposition had long-since ceased. The statement that "there is no evidence to suggest that the 5 ka age is suspect" is similarly dubious therefore and takes little account of the wider depositional context.

\section{Radiocarbon-based ages on KOT}

More than ca. $60{ }^{14} \mathrm{C}$-derived ages relating to the deposition of the KOT have been published (see reviews by Froggatt and Lowe, 1990; Gillespie et al., 1992; Newnham et al., 2007c; Lowe et al., 2008a). We acknowledge that many of the ${ }^{14} \mathrm{C}$ ages acquired over many decades for the KOT range from ca. 20,000 to ca. $25,000{ }^{14} \mathrm{C}$ BP. Such a span means that many ages must be several thousand ${ }^{14} \mathrm{C}$-years or more astray of the true eruption age, given that the Kawakawa/Oruanui eruption would have lasted months, not millennia (Lowe et al., 2009). Part of the problem has been a dearth of carbonaceous material directly associated

with the eruption and because anomalously young ages have arisen as a result of contamination of organic sediments especially in high rainfall environments (Lowe et al., 
2008a). Consequently, the current best estimate for the age of the KOT is $22,590 \pm 230{ }^{14} \mathrm{C}$ $\mathrm{BP}$, an activity-weighted pooled mean age from four samples of small carbonised branch fragments (from four separate sites) embedded within the non-welded Oruanui ignimbrite emplaced during the Kawakawa/Oruanui eruption (Wilson et al., 1988). These fragments demonstrably represent short-lived material intimately associated with the eruption whereas most other ages for the KOT are usually from material less closely associated with the eruption and of wider age range (Lowe et al., 2008a). Support for this ${ }^{14} \mathrm{C}$ age estimate is provided by the stratigraphic superposition of ages on tephras which overlie the KOT (as noted earlier) and also those which underlie it, and by several luminescence and ${ }^{14} \mathrm{C}$ ages (see Lowe et al., 2008a). In contrast, Alloway et al. (2005) estimated a calendar age for the KOT of ca. $21.4 \mathrm{ka}$ (no error reported) using astronomical tuning from sediments at core site 1123 of ODP Leg 181. However, Allan et al. (2008) have shown that such tuning was likely compromised because of inadequate sampling resolution.

The mean radiocarbon age $22,590 \pm 230{ }^{14} \mathrm{C}$ BP has a calibrated age of $27,097 \pm 957$ cal BP $(2 \sigma)$ derived from the high-resolution Cariaco Basin dataset of Hughen et al. (2006). We emphasise that the error, although around 1000 years, is at the 95\% probability level. Although just outside the range of IntCal04, the favoured ${ }^{14} \mathrm{C}$ age is within range of the new IntCal09 curves (to be published by 2010) which extend to 50,000 cal BP. The calibrated age range reported here will not change much with IntCal09. Nevertheless, it remains possible that new samples of high-quality charcoal derived from short-lived plant material pyrolised during emplacement of Oruanui ignimbrite, or other optimal dating material, could provide ${ }^{14} \mathrm{C}$ ages that require the age of the KOT to be reconsidered. 


\section{Conclusion}

The age of the KOT, currently estimated at ca. $27 \pm 1 \mathrm{ka}$ cal BP $(2 \sigma)$ from ${ }^{14} \mathrm{C}$ dating, is indeed critical to many palaeoenvironmental as well as volcanological studies in New Zealand and the southwest Pacific region. The IRSL age of approximately $17.0 \mathrm{ka}$, reported by Grapes et al. (2010) for the KOT, is untenable because tephrostratigraphic and palaeoenvironmental evidence conflict with such young IRSL ages for loess deposition in southern North Island, essential statistical treatments and error determinations are lacking, and data reported are inconsistent. Nevertheless, efforts to improve the precision of the age of KOT, including through the use of improved luminescence dating via appropriate singlegrain analysis, and by ${ }^{14} \mathrm{C}$ dating of optimal carbonaceous materials, should continue.

\section{Acknowledgements}

We appreciated comments from Mark Bateman (University of Sheffield) about luminescence dating protocol, from Paula Reimer (Queen's University Belfast) about IntCal09, and from Rodney Grapes (Korea University) about some of the difficulties in dating Kawakawa/Oruanui tephra. We also thank Rainer Grün for helpful comments.

Editorial handling by: R. Grün

\section{References}

Allan, A.S.R., Baker, J.A., Carter, L., Wysoczanksi, R.J., 2008. Reconstructing the Quaternary evolution of the world's most active silicic volcanic system: insights from a 1.65 Ma deep ocean tephra record sourced from the Taupo Volcanc Zone, New Zealand. Quaternary Science Reviews 27, 2341-2360. 
Alloway, B., Pillans, B., Carter, L., Naish, T., Westgate, J., 2005. Onshore-offshore correlation of Pleistocene rhyolitic eruptions from New Zealand: implications for TVZ eruptive history and paleoenvironmental construction. Quaternary Science Reviews 24, $1601-1622$.

Alloway, B.V., Lowe, D.J., Barrell, D.J.A., Newnham, R.M.., Almond, P.C., Augustinus, P.C., Bertler, N.A., Carter, L., Litchfield, N.J., McGlone, M.S., Shulmeister, J., Vandergoes, M.J., Williams, P.W., NZ-INTIMATE members, 2007. Towards a climate event stratigraphy for New Zealand over the past 30,000 years (NZ-INTIMATE project). Journal of Quaternary Science 22, 9-35.

Almond, P.C., Shanhun, F.L., Rieser, U., Shulmeister, J., 2007. An OSL, radiocarbon and tephra isochron-based chronology for Birdlings Flat loess at Ahuriri Quarry, Banks Peninsula, Canterbury, New Zealand. Quaternary Geochronology 2, 4-8.

Bateman, M.D., Boultera, C.H., Carra, A.S., Frederick, C.D., Peter, D., Wilder, M., 2007. Detecting post-depositional sediment disturbance in sandy deposits using optical luminescence. Quaternary Geochronology 2, 57-64.

Berger, G.W., Pillans, B.J., Palmer, A.S., 1994. Test of thermoluminescence dating of loess from New Zealand and Alaska. Quaternary Science reviews 13, 309-333.

Blaauw, M., Bakker, R., Christen, J.A., Hall, V.A., van der Plicht, J., 2007. Bayesian framework for age-modelling of radiocarbon dated peat deposits: case studies from The Netherlands. Radiocarbon 49, 357-367.

Blockley, S.P.E., Blauuw, M., Bronk Ramsey, C., van der Plicht, J., 2007. Building and testing age models for radiocarbon dates in Lateglacial and Early Holocene sediments. Quaternary Science Reviews 26, 1915-1926.

Bronk Ramsey, C., 2008. Depositional models for chronological research. Quaternary Science Reviews 27, 42-60. 
Buck, C.E., Higham, T.F.G., Lowe, D.J., 2003. Bayesian tools for tephrochronology. The Holocene, 13, 639-647.

Carter, L., Manighetti, B., Ganssen, G., Northcote, L., 2008. Southwest Pacific modulation of abrupt climate change during the Antarctic Cold Reversal-Younger Dryas. Palaeogeography, Palaeoclimatology, Palaeoecology 260, 284-298.

Demuro, M., Roberts, R.G., Froese, D.G., Arnold L.J., Brock, F., Bronk Ramsey, C., 2008. Optically stimulated luminescence dating of single and multiple grains of quartz from perennially frozen loess in western Yukon Territory, Canada: comparison with radiocarbon chronologies for the late Pleistocene Dawson tephra. Quaternary Geochronology 3, 346-364.

Duller, G.A.T., 1994. Luminescence dating using feldspars: a test case from southern New Zealand. Quaternary Geochronology (Quaternary Science Reviews) 13, 423-427.

Duller, G.A.T., 1996. The age of the Koputaroa dunes, southwest North Island, New Zealand. Palaeogeography, Palaeoclimatology, Palaeoecology 121, 105-114.

Duller, G.A.T., 2004. Luminescence dating of Quaternary sediments: recent advances. Journal of Quaternary Science 19, 183-192.

Eden, D.N., Hammond, A.P., 2003. Dust accumulation in the New Zealand region since the last glacial maximum. Quaternary Science Reviews 22, 2037-2052.

Fattahi, M., Stokes, S., 2003. Dating volcanic and related sediments by luminescence methods: a review. Earth-Science Reviews 62, 229-264.

Froggatt, P.C., Lowe, D.J., 1990. A review of late Quaternary silicic and some other tephra formations from New Zealand: their stratigraphy, nomenclature, distribution, volume, and age. New Zealand Journal of Geology and Geophysics 33, 89-109. 
Gillespie, R., Hammond, A.P., Goh, K.M., Tonkin, P.J., Lowe, D.C., Sparks, R.J., Wallace, G., 1992. AMS dating of a late Quaternary tephra at Graham's Terrace, New Zealand. Radiocarbon 34, 21-27.

Grapes, R., Rieser, U., Wang, N., 2010. Optical luminescence dating of a loess section containing a critical tephra marker horizon, SW North Island of New Zealand. Quaternary Geochronology 5, 164-169.

Hajdas, I., Lowe, D.J., Newnham, R.M., Bonani, G., 2006. Timing of the late-glacial climate reversal in the Southern Hemisphere using high-resolution radiocarbon chronology for Kaipo bog, New Zealand. Quaternary Research 65, 340-345.

Hughen, K.A., Southon, J., Lehman, S., Bertrand, C., Turnbull, J., 2006. Marine-derived ${ }^{14}$ C calibration and activity record for the past 50,000 years updated from the Cariaco Basin. Quaternary Science Reviews 25, 3216-3227.

Litchfield, N.J., Berryman, K.R., 2005. Correlation of fluvial terraces within the Hikurangi Margin, New Zealand: implications for climate and baselevel controls. Geomorphology 68, 291-313.

Litchfield, N.J., Berryman, K.R., 2006. Relations between postglacial fluvial incision rates and uplift rates in the North Island, New Zealand. Journal of Geophysical Research 111, F02007, doi: 10.1029/2005JF000374 (15 pp).

Lowe, D.J., Shane, P.A.R., Alloway, B.V., Newnham, R.M., 2008a. Fingerprints and age models for widespread New Zealand tephra marker beds erupted since 30,000 years ago: a framework for NZ-INTIMATE. Quaternary Science Reviews 27, 95-126.

Lowe, D.J., Tonkin, P.J., Palmer, A.S., Palmer, J. 2008b. Dusty horizons. In: Graham, I.J. (Ed.), A Continent on the Move: New Zealand Geoscience into the $21^{\text {st }}$ Century. Geological Society of New Zealand Miscellaneous Publication 124, 270-273. 
Lowe, D.J., Blaauw, M., Bateman, M.D., Buck, C.E., Newnham, R.M., 2009. Introducing SUPRAnet and some implications for age modelling in the Australasian INTIMATE project. In: Cortes, G., Vandergoes, M., Bostock, H. (Eds), Past Climates Meeting, 15$17^{\text {th }}$ May, Wellington. GNS Science Miscellaneous Series 23, 38.

Manville, V., Wilson, C.J.N., 2004. The 26.5 ka Oruanui eruption, New Zealand: a review of the roles of volcanism and climate in the post-eruptive sedimentary response. New Zealand Journal of Geology and Geophysics 47, 525-547.

Marx, S.K., McGowan, H.A., Kamber, B.S., 2009. Long-range dust transport from eastern Australia: a proxy for Holocene aridity and ENSO-type climate variability. Earth and Planetary Science Letters 282, 167-177.

Newnham, R.M., Eden, D.N., Lowe, D.J., Hendy, C.H., 2003. Rerewhakaaitu Tephra, a landsea marker for the Last Termination in New Zealand, with implications for global climate change. Quaternary Science Reviews 22, 289-308.

Newnham, R.M., Lowe, D.J., Giles, T.M., Alloway, B.V., 2007a. Vegetation and climate of Auckland, New Zealand, since ca. 32000 cal. yr ago: support for an extended LGM. Journal of Quaternary Science 22, 517-534.

Newnham, R.M., Vandergoes, M.J., Hendy, C.H., Lowe, D.J., Preusser, F., 2007b. A terrrestrial palynological record for the last two glacial cycles from southwestern New Zealand. Quaternary Science Reviews 26, 517-535.

Newnham, R.M., Vandergoes, M.J., Garnett, M.H., Lowe, D.J., Prior, C., Almond, P.C. 2007c. Test of AMS ${ }^{14} \mathrm{C}$ dating of pollen concentrates using tephrochronology. Journal of Quaternary Science 22, 37-51.

Palmer, A.S., Pillans, B.J., 1996. Record of climatic fluctuations from ca. 500 ka loess deposits and paleosols near Wanganui, New Zealand. Quaternary International 34-36, $155-162$. 
Pillans, B.J., McGlone, M.S., Palmer, A.S., Mildenhall, D.C., Alloway, B.V., Berger, G.W., 1993. The Last Glacial Maximum in central and southern North Island, New Zealand: a palaeoenvironmental reconstruction using the Kawakawa Tephra Formation as a chronostratigraphic marker. Palaeogeography, Palaeoclimatology, Palaeoecology 101, 283-304.

Shepherd, M.J., Price, D.M., 1990. Thermoluminescence dating of late Quaternary dune sand, Manawatu/Horowhenua area, New Zealand: a comparison with ${ }^{14} \mathrm{C}$ age determinations. New Zealand Journal of Geology and Geophysics 33, 535-539.

Suggate, R.P., Almond, P.C., 2005. The Last Glacial Maximum (LGM) in western South Island, New Zealand: implications for the global LGM and MIS 2. Quaternary Science Reviews 24, 1923-1940.

Vandergoes, M.J., Newnham, R.M., Preusser, F., Hendy, C.H., Lowell, T.V., Fitzsimons, S.J., Hogg, A.G., Kasper, H.U., Schluchter, C., 2005. Regional insolation forcing of late Quaternary climate change in the Southern Hemisphere. Nature 436, 242-244.

Wilson, C.J.N., 2001. The 26.5 ka Oruanui eruption, New Zealand: an introduction and overview. Journal of Volcanology and Geothermal Research 112, 133-174.

Wilson, C.J.N., Switsur, R.V., Ward, A.P., 1988. A new ${ }^{14}$ C age for the Oruanui (Wairakei) eruption, New Zealand. Geological Magazine 125, 297-300. 